aspects.: thesis for a candidate degree in philology : speciality 10.02.04]. Zhytomyr, $312 \mathrm{p}$.

11. Simvoly $\square$, znaki, e $\square$ mblemy $\square: E \square n c y \square$ klopediya (2005) [Symbols, signs, emblems : encyclopedia] / edited by V. L. Telicy $\square$ n; authors V. E $\square$. Bagdasaryan, I.B. Orlov, V.L. Telicy $\square$ n. 2-e izd. Moscow : LOKID-PRESS, 494 p.

12. Tresidder Dzh. (1999) Slovar $\square$ simvolov [Dictionary of symbols]. Moscow. Retrieved from https://www. lesjeunesrussisants.fr/dictionnaires/documents/ DICTIONNAIRE_RUSSE_DES_SYMBOLES.pdf

13. Tsapiv A.O. (2018) Arkhetypni obrazy v anhliiskykh literaturnykh kazkakh (na materiali kazky Dzhona Raskina "Korol zolotoi riky") [Archetypical images in English literary fairy tales (case study of John Ruskin's fairy tale "The king of the golden river")] Naukovyi visnyk Khersonskoho derzhavnoho universytetu. Seriia : "Perekladoznavstvo ta mizhkulturna komunikatsiia" Vyp. 3. Kherson, pp. 52-57.

14. Yung K. G. (1996) Dusha i mif. Shest $\square$ archetipov [Soul and myth. Six Archetypes]. Kiev: Gosudarstvennaya biblioteka Ukrainy $\square$ dlya yunoshestva, 384 p.

15. Benedict, R. (1961) Patterns of Culture. London: Routledge. 212 p.

16. Bodkin, M. (1968) Archetypal Patterns in Poetry. London: Oxford university press. $356 \mathrm{p}$.

17. Campbell, J. (2002) The Inner Reaches of Outer Space: Metaphor as Myth and as Religion. Novato, California: New World Library. $148 \mathrm{p}$.

18. The Greenwood encyclopedia of folktales and fairy tales (2008) / ed. by Donald Haase. Westport: Greenwood Press. 1202 p.

19. Reed, A. W. (1975) Myths and Legends of Australia. New York: Taplinger Publishing Co. $256 \mathrm{p}$.

20. Rolls, M., Johnson, M. (2011) Historical Dictionary of Australian Aborigines. Lanham, Toronto, Plymouth, UK: The Scarecrow Press, Inc. 214 p.

21. Westbury, Atha (1897) Australian Fairy Tales. London: Ward, Lock, \& Co., Limited, Warwick House, Salisbury Square, E.C. New York and Melbourne. 360 p.

\title{
AMERICAN MARKETING DISCOURSE AND MULTIMODALITY: COGNITIVE AND COMMUNICATIVE ASPECTS
}

\author{
Stodolinska Yuliya Valeriivna, \\ Candidate of Philological Sciences, \\ Assistant Professor at the Department of English Philology \\ Petro Mohyla Black Sea National University \\ yuliya.stodolinska@gmail.com \\ orcid.org/0000-0002-4515-0323
}

Marketing discourse is built on new conceptual images, it also encompasses the relationships between the participants of this discourse, viewed in their language expression, and possesses features which are characteristic of this discourse in the modern world. The study of marketing discourse from a multimodal perspective is one of the key issues in contemporary linguistics.

The purpose of the article is to reveal the cognitive and communicative aspects of marketing discourse as a whole and of multimodality as one of its characteristic features in particular. The methodology of this research, which is grounded on the aim and the tasks, requires an integrative multidisciplinary approach which combines the methods and former research findings of such disciplines as cognitive linguistics, discourse studies, communicative linguistics, semiotics, visual semantics. In the context of the article business discourse is defined as a type of institutional discourse, the key attributes of marketing discourse being a type of business discourse are singled out, the specifics of multimodality as one of the characteristic features of marketing discourse are outlined.

It is assumed that multimodality is one of the key features of American marketing discourse which is a type of business discourse. Marketing discourse as well as other types of business discourse is a variety of institutional discourse, its participants are members of the professional community of business people and their clients, whose interaction is organized around the key notions of business in order to achieve the aims of communication. Marketing discourse is a language-based set of activities aimed at creating the product and launching it on the market in the most successful way. Multimodality, interaction, dynamism, consistency, detail, creativity, and didacticism are the characteristic features of the analyzed discourse. It has been established that multimodality encompasses the use of several semiotic modes (numerous ways of their combinations) which include content and expression in the design of a semiotic product or event.

Key words: business discourse, cognition, communication, institutional discourse, non-verbal component, semiotic mode, verbal component. 


\title{
АМЕРИКАНСЬКИЙ ДИСКУРС МАРКЕТИНГУ ТА МУЛЬТИМОДАЛЬНІСТЬ: КОГНІТИВНИЙ ТА КОМУНІКАТИВНИЙ АСПЕКТИ
}

\author{
Стодолінська Юлія Валеріївна, \\ кандидат фрілологічних наук, \\ старший викладач кафедри англійської фрілології \\ Чорноморський національний університет імені Петра Могили \\ yuliya.stodolinska@gmail.com \\ orcid.org/0000-0002-4515-0323
}

\begin{abstract}
Американський дискурс маркетингу базується на нових концептуальних образах, охоплює відносини між учасниками такого дискурсу, наділений рисами, характерними цьому дискурсу у сучасному глобалізованому світі. Дослідження американського дискурсу маркетингу з точки зору мультимодальності є одним з ключових питань у сучасній лінгвістиці.

Meта статті полягає у розкритті когнітивного та комунікативного аспектів американського дискурсу маркетингу загалом та безпосередньо мультимодальності як характерної ознаки аналізованого дискурсу. Методологія дослідження, яка зумовлена метою та поставленими завданнями, базується на використанні інтегрованого мультидисциплінарного підходу, який охоплює методи та попередні наукові розвідки таких галузей, як когнітивна лінгвістика, дискурсологія, комунікативна лінгвістика, семіотика, візуальна семантика. У статті визначено, що бізнес дискурс є видом інституційного дискурсу, виокремлено ключові характеристики американського дискурсу маркетингу як підтипу бізнес дискурсу, розкрито специфріку мультимодальності як ключової характеристики американського дискурсу маркетингу.

Мультимодальність визначається однією з характерних рис американського дискурсу маркетингу, який є підтипом бізнес дискурсу. Дискурс маркетингу, як і інші різновиди бізнес дискурсу, є інституційним дискурсом. Учасниками досліджуваного дискурсу є члени професійної спільноти представників бізнесу та їх клієнти, взаємодія яких зосереджена навколо ключових понять бізнесу для досягнення цілей комунікації. Дискурс маркетингу охоплює набір вербальних та невербальних дій, спрямованих на створення продукту та запуск його на ринку найуспішнішим способом. Мультимодальність, взаємодія, динамізм, послідовність, детальність, креативність та дидактизм є характерними рисами американського дискурсу маркетингу. Встановлено, що мультимодальність базується на використанні декількох семіотичних режимів (а також численних способах їх комбінування), які включають план змісту та план вираження у створенні семіотичного продукту.
\end{abstract}

Ключові слова: бізнес дискурс, вербальний компонент, інституційний дискурс, комунікація, невербальний компонент, пізнання, семіотичний режим.

\section{Introduction}

Interrelation between language and social reality, language and business is under constant attention of contemporary linguistics. The study of business discourse and its types is very topical now. Business discourse is considered to be contextual and intertextual, self-reflexive and self-critical, it is founded on the notions of discourse as situated action and of language at work.

Researchers focusing on business discourse at the end of the twentieth - beginning of the twenty-first century were faced with the task of defining the field of research and with identifying those approaches and methodologies that could be useful in understanding how business people use language to achieve their goals (e.g. F. Bargiela-Chiappini \& S. Harris; F.Bargiela-Chiappini \& C. Nickerson). Researchers have referred to a number of fields and disciplines in their investigation of language at work, such as genre theory, discourse analysis, organizational communication, and applied linguistics. This cross-disciplinarity has led to a number of different ways of thinking about business language and different contextual variables that can be of influence on how people talk and write at work.

Actuality of the work lies in focusing on contemporary discourse types study, especially on new types of business discourse, which currently cause particular interest. Internet resources ensured the research of new types of business discourses. Marketing discourse is one of the examples of such discourses which is becoming a popular research topic in different language studies. Marketing discourse is built on new conceptual images, it also encompasses the relationships between the participants of this discourse, viewed in their language expression, and possesses features which are characteristic of this discourse in the modern world.

Attention to this discourse is caused not only by its great importance in the society, influence of mass media but also by interest in studying the disciplines, which are connected with business such as marketing, management, production, etc. The issues of semiotics, visual semantics, especially the interaction of verbal and nonverbal components have also recently become quite 
topical in different branches of linguistics (the works of O. Anisimova, A. Bernatska, G. Kress, T. Leeuwen, M. Muckenhaupt, U. Oomen, S. Sauerbier, Y. Sorokin, M. Voroshilova, etc. are to name a few) (Kress, Leeuwen, 2017, Muckenhaupt, 2006). Thus, the study of marketing discourse from a multimodal perspective is a rather contemporary topic which is characterized by novelty in the field and the necessity of defining its main characteristics and peculiar features.

The purpose of the article is to reveal the cognitive and communicative aspects of marketing discourse as a whole and of multimodality as one of its characteristic features in particular. In order to achieve the aim it is important to fulfill the following tasks: to characterize the notion of business discourse as a type of institutional discourse, to determine the key features of marketing discourse, to outline the specifics of multimodality as one of the key features of marketing discourse. The methodology of research, which is grounded on the aim and the tasks, requires an integrative multidisciplinary approach that combines the methods and former research findings of such disciplines as cognitive linguistics, discourse studies, communicative linguistics, semiotics, visual semantics. The findings of the study are presented in three subsequent parts, each one of which focuses on the solution of a framed task followed by the general conclusions.

\section{Business Discourse}

Discourse refers to formal discussion of a topic. In a linguistic sense, discourse is a connected series of utterances, reconstructed in terms of a larger unit (Dijk, 1997:3). Discourse, in turn, can be studied by deconstructing it to macro-structures. Macro-structures are semantic characterizations - compound sentences and discourse sequences. Macro-structures are the result of cognitive processes of comprehension, grounded on generalization, abstraction and reducing the discourse of irrelevant information: "What is important information not only depends on the semantic structure of the text but also on the pragmatic functions of the discourse" (Dijk, 1997: 243-244). This, of course, in parts justifies some degree of subjectivity in analysis. As the focus of the conceptual analysis is on determining the topics in a range of passages and discourses, all of which use a grammatically similar but semantically different vocabulary, establishing systematic relations between the semantic representations of the passages and discourses and an assigned topic is left to creating categories and comparing the attributes of the various sources to each other.
Research in contemporary linguistics has led to the appearance of the term discourse, which was first introduced in 1952 in the context of discourse analysis. Gradually more interpretations of this term appeared. Discourse began to be defined as some language abstraction, which virtually exists in depths of live national language, or artificial language restrictions, which perform a certain social function, "substitute" sublanguages. Languages of science, art can be seen as an illustration of such artificial "sublanguages". Every "sublanguage" like this creates its own picture of the world, a special "mental world". Every discourse is a special sublanguage, special linguistic practice, which is employed in specific functional spheres of language community (Dijk, 1997).

Business discourse is all about how people communicate using talk or writing in commercial organizations in order to get their work done (Bargiela-Chiappini, Nickerson, 2002: 303). Business discourse has been influenced by a number of different fields and disciplines including discourse analysis, conversation analysis, the pragmatics of interaction, ethnography, genre theory, and organizational communication. Business discourse as contextual and intertextual, self-reflexive and self-critical although not necessarily political, is grounded on the twin notions of discourse as situated action and of language at work (Bargiela-Chiappini, Nickerson, 2002: 310).

The problem of defining business discourse lies in determining its place in the continuum of general national language (in this case - American variant of English). Business, as a special form of economic activity has been defined for the first time in the second half of the XXth century. When economic theory has been divided into macro- and microeconomics, business became the object of microeconomics research. Thus, business discourse can be considered as a variety of discourse of macroeconomics, even though some think that separation of economic discourse, in spite of rapid development of economic theory, did not take place.

Discourse is produced on the level of macroeconomics or on the level of the whole society; however, it also has its linguistic practice: parliamentary hearings of economic issues, discussion of economic legal acts, public speeches of leading economists, etc. Unlike economic discourse, business discourse can encompass four main spheres: commerce, production, finance and brokerage. Every sphere has its own peculiarities, which gives us good reason to consider them as varieties of business discourse. The pecu- 
liarities are caused by thematic and intentional orientation, terminology and peculiarities of its usage, rules of professional interaction between participants of the communication process.

Thus, English business discourse is a variety of institutional discourse, which serves the professional community of business people and their clients and is organized around the key notions of business.

\section{Marketing discourse}

Marketing is considered to be one of the fields of business. It is too often confused with selling. Marketing focuses on the product before it even exists. It is up to marketing to do everything possible to make the product work: determine how to launch, price, distribute, and promote product/ service offerings to the marketplace, monitor the results and improve the offering over time. The aim of marketing is to create value by offering superior solutions, saving buyer search and transaction time and effort, and delivering to the whole society a higher standard of living. Marketing practice today must go beyond a fixation of transactions. The field is not restricted to a department that creates ads, selects media, sends out direct mail, and answers customer questions. It is a larger process of systematically figuring out what to make, how to bring it to the customer's attention, make it easy to access, and how to keep the customer wanting to buy more from you.

Marketing discourse is one of the types of business discourse. "Discourse" is here, in accordance with e.g. N. Fairclough (2010), T.A.van Dijk (1997), T. van Leeuwen, (2017), referred to as language use as a social practice. In marketing, discourse is considered to be not beside marketing actions such as strategy formulation, designing of market research, positioning etc. but above, in other words, overriding and embodying the latter. Conceiving of marketing practice as discourse, i.e. as a language based set of activities, hence pays attention to the primary role of talk and writing in marketing work.

The conception of marketing consists of the notions that express all the forms and types of interactions (commerce, trade, barter, deal, exchange), people involved in the selling-buying relationships (sellers and buyers) and the objects of exchange (commodities). The economic theory has worked out the concept of marketing, which is represented by the 4P's - product, place, price, promotion, and is defined as interconnected forms and methods of taking charge in the civilized market economy, which involves all the stages of the movement of the product, starting from the study of the needs, wants, demands, production and creation of services, taking them to the end-consumer and finishing with the follow-up after selling (Bargiela-Chiappini, Nickerson, 2002: 263).

Accordingly, marketing discourse is one of the types of business discourse, which is a language-based set of activities aimed at creating the product and introducing it to the market in the best way possible. It is a cognitive and communicative activity, restricted by institutional boundaries, aimed at the realization of discourse participants' status and role capabilities and the achievement of social, business and marketing aims. Multimodality, interaction, dynamism, consistency, detail, creativity, and didacticism are the characteristic features of the analyzed discourse.

\section{Multimodality}

In order to give a more detailed description of the marketing discourse it is necessary to look at the peculiarities of marketing discourse analysis. In the world of constantly emerging technologies, multimodality is an important part of contemporary marketing discourse.

Discourse analysis focuses on the description of the organization of language in terms of linguistic units larger than sentences or clauses, such as conversational exchanges or texts. Within marketing discourse, research has been used to establish how business talk is organized more generally (that is, in speaker turns, content episodes, and so on). It follows that discourse analysis is therefore concerned with language use in its social context, and in particular with interaction between speakers.

One of the defining features of business discourse research is that it has not relied on any one approach or methodology. Business discourse research has been both descriptive and prescriptive in its research aims. With its roots partly in the business communication tradition in North America and the applied linguistics tradition elsewhere, much of the early research that was carried out at the end of the twentieth century was pedagogically motivated. Business language was investigated not as an end to itself, but largely to inform teaching or training programs, for pre- or post-experience business people respectively.

The advent of new media such as electronic mail, the web, social networks has revolutionized interpersonal communication in the business world, and has opened up a series of new research areas for the business discourse researcher to explore. The web has introduced new vistas on marketing and advertising that exploit the potential of multimedia communication 
to secure an increasingly multicultural share of the international market. More importantly perhaps, the digitization age has been responsible for a shift from monomodality, expressed in static generic types such as the traditional, printed business letter, to increasingly complex and dynamic examples of 'multimodality' (e.g. online commercial websites). In turn, the use of such new, and particularly web-based, media has cultivated an interest in the multimodal signification of meaning inherent in such media (computers, email, messengers, cell phones, tablets, etc.), involving as they do not only text, but also visual and sound-based modalities. A de-emphasis on writing in exchange for an emphasis on other representational modes (i.e. pictures, sounds, films, etc.) provides researchers with an opportunity to broaden their approach to how 'text' is viewed (Kress, 2010).

Multimodality is the foundational construct that underpins the theory of communication proposed by G. Kress and T. Leeuwen in Multimodal Discourse. The authors define multimodality as 'the use of several semiotic modes in the design of a semiotic product or event, together with the particular way in which the modes are combined'. G. Kress and van T. Leeuwen envisage two strata, Content and Expression, which encompass four domains of practice: Discourse and Design (substrata of Content), and Production and Distribution (substrata of Expression) (Kress, Leeuwen, 2017).

A discourse is essentially a resource or a semiotic mode, that is a socially constructed body of knowledge, developed in a specific context (e.g. institutional, geographical, social, etc.) by a particular community of social actors (e.g. business practitioners, experts, family members, etc.) to suit that community's specific needs (e.g. to work, act, bond, etc.). Discourses can be realized differently: marketing discourse, for instance, can be realized in writing or speech and each of these in turn, or in combination, can be realized in various media (e.g. a product brochure, a product demo speech, etc.). Discourses are, thus, independent of genre and design. The second stratum, Design, is defined as '(uses of) semiotic resources, in all semiotic modes and combinations of semiotic modes', to realize a given Discourse in the context of a specific communication situation. Essentially, Design creates the communication situation in which socially constructed knowledge evolves into 'social (inter-) action' (Kress, Leeuwen, 2017:5).

The particular attractiveness of multimodality for Marketing Discourse is its inherent multi- disciplinary nature. In this view, language still informs a variety of modes of meaning making (e.g. narrative, poetry etc.) but is displaced as a privileged meaning-making mode in favor of image, sound or film; the tensions between semiotic modes become an important topic of research (Iedema, 2003: 123). Within this new multimodal landscape, electronic communication, economic globalization and multiculturalism are responsible for the dissolution of traditional, linear and hierarchical representational practices and genres (Iedema, 2003: 38).

Thus, multimodality is the use of several semiotic modes in the design of a semiotic product or event, which encompasses discourse, design, product, and distribution. This peculiarity of marketing discourse, as well as others are important factors in making marketing discourse a successful type of business discourse as a whole.

\section{Conclusions}

The research has made it possible to arrive at the conclusion that multimodality is one of the key features of American marketing discourse which is a type of business discourse. Marketing discourse as well as other types of business discourse is a variety of institutional discourse, its participants are members of the professional community of business people and their clients, whose interaction is organized around the key notions of business in order to achieve the aims of communication.

Unlike the other types of business discourse, marketing discourse is a language-based set of activities aimed at creating the product and launching it on the market in the most successful way. It is a cognitive and communicative activity, which involves constructing the inner and outer design of the product or description of a service, defining the pricing strategy, identifying the details of logistics and positioning of the products and services on the market, creating successful promotional activities. The achievement of the business, social and marketing aims of the analyzed discourse require an innovative and dynamic approach of all the participants of the discourse. Multimodality, interaction, dynamism, consistency, detail, creativity, and didacticism are the characteristic features of the analyzed discourse.

It has been established that multimodality encompasses the use of several semiotic modes which include content and expression in the design of a semiotic product or event. The number of semiotic modes used as well as numerous ways of combining them makes this peculiarity of marketing discourse rather unique and leaves 
a vast area of problems to examine. The prospective of future research features the study of the combination of static and dynamic semiotic modes in American marketing discourse.

\section{ЛITЕРАТУРА}

1. Bargiela-Chiappini F., Nickerson C. Business Discourse : Old Debates, New Horizons. International Review of Applied Linguistics in Language Teaching, (IRAL), 2002. № 40 (4). P. 273-381.

2. Dijk T.A. Text and Context: Explorations in the Semantics and Pragmatics of Discourse. London : Longman, 1997. $292 \mathrm{p}$.

3. Fairclough N. Critical Discourse Analysis : the critical study of language. London and New York : Longman, 2010. 268 p.

4. ledema R. Multimodality, Resemiotization: Extending the Analysis of Discourse as Multi-semiotic Practice. Visual Communication, 2003. № 2(1). P. 29-57.

5. Kress G. Literacy in the New Media Age. New York : Routledge, 2003. 208 p.

6. Kress G., Leeuwen T. Multimodal Discourse. The Modes and Media of Contemporary Communication. London : Arnold, 2001. 152 p.
7. Muckenhaupt M. Text und Bild. Grundfragen der Beschreibung von Text-Bild-Kommunikationen aus sprachwissenschaftlicher Sicht. Tübingen : Gunter Narr, 2006. 454 s.

\section{REFERENCES:}

1. Bargiela-Chiappini, F., \& Nickerson, C. (2002). Business Discourse: Old Debates, New Horizons. IRAL International Review of Applied Linguistics in Language Teaching, 40 (4).

2. Dijk, T.A. (1997). Text and Context: Explorations in the Semantics and Pragmatics of Discourse. London : Longman.

3. Fairclough, N. (2010). Critical discourse analysis: The critical study of language. Harlow : Longman.

4. ledema, R. (2003). Multimodality, Resemiotization: Extending the Analysis of Discourse as Multi-semiotic Practice. Visual Communication, 2(1), 29-57.

5. Kress, G.R. (2010). Literacy in the New Media Age. London : Routledge.

6. Kress, G.R., \& Leeuwen, T.V. (2017). Multimodal Discourse. The Modes and Media of Contemporary Communication. Bloomsbury : Bloomsbury Academic.

7. Muckenhaupt M. (2006). Text und Bild. Grundfragen der Beschreibung von Text-Bild-Kommunikationen aus sprachwissenschaftlicher Sicht. Tübingen : Gunter Narr.

\title{
ДИНАМІКА ВАРІАНТНОСТІ Й СИНОНІМIÏ ЕКОНОМІЧНИХ ТЕРМІНІВ НІМЕЦЬКОÏ МОВИ
}

\author{
Шерстюк Ольга Ігорівна, \\ кандидат технічних наук, \\ старший викладач кафедри філології \\ Одеський національний морський університет \\ olusha972@gmail.com \\ orcid.org/0000-0002-0482-2656
}

\begin{abstract}
У статті розәлядаються парадигматичні параметри економічної терміносистеми німецької мови, а саме варіантність і синонімія. Метою дослідження є обгрунтування системної природи економічної термінології на основі аналізу варіантних і синонімічних відносин. Використана комплексна методика. Описовий метод застосовується для інвентаризації термінологічних одиниць, інтерпретації особливостей їх структури та функціонування на сучасному етапі розвитку німецької мови. Для дослідження семантичної структури терміноодиниць застосований метод компонентного аналізу. Структурний метод став інструментом опису парадигматики економічної терміносистеми, зокрема варіантності й синонімії термінів. За допомогою цих методів отримані такі результати. Виявлено, що варіанти терміносистеми економіки представлені віддієслівними іменниками, які утворені способом імпліцитної (неморфологічної) деривації й позначають процес із його результатом і за допомогою дієслівної основи та суфріксів -e, -ung, -ing, які позначають процес, результат дії й функцію відповідно.

Під час дослідження синонімічних термінів виділені три типи синонімічних відносин: між монолексемними термінами, між полілексемними термінами та між моно- й полілексемними термінами. У синонімічні відношення між монолексемними термінами вступають прості однокореневі терміни, похідні терміни з однаковими та різними префріксами і складні терміни з повною й частковою заміною компонентів термінів. Доведено, що синонімія між похідними термінами представлена великою кількістю рядів. Це пояснюється тим, що прості терміни не здатні мотивувати наукове поняття. Синонімія між складними термінами посідає в економічній термінології німецької мови центральне місце й характеризується різноманіттям проявів. У досліджуваній термінології синонімія між термінами иієї структури є найпродуктивнішою. Виділено структурні моделі вільних словосполучень, що утворюють синонімічні ряди в результаті заміни визначальних компонентів і компонентів, які визначаються.
\end{abstract}

